\title{
ILUMINISMO E COERÇÃO
}

\author{
José N. H eck \\ Universidade Federal de Goiás \\ heck@internetional.com.br
}

RESUMO: A D outrina do direito apenas nas últimas décadas voltou a merecer o interesse dos estudiosos da filosofia. 0 presente texto procura mostrar a filiação iluminista da ciência kantiana do direito. 0 artigo privilegia o caráter racional das concepções jurídicas do pensador alemão.

Palavras-chave: Kant, faculdade de coagir, direito racional, filosofia do direito.

\section{Introdução}

A filosofia política moderna nasce acasalada com a coerção. Em M aquiavel (1469-1527) eem H obbes (1588-1679) ela se encontra à flor da pele. Também Rousseau (1712-1778) só é um filósofo político, e não apenas um crítico cultural, porque se propõe a legitimar les fers que mantêm os homens agrilhoados, sem que para isso haja uma explicação natural satisfatória; ${ }^{1}$ H egel (1770-1831), por sua vez, não se conformou com tal estatuto da Modernidade. Sua noção de liberdade substancial é grega, em virtude de o ônus da prova da moderna quaestio iuris ficar com quem dele reivindica uma subjetividade autônoma. É a outra parte que deve justificar a linha que divide a fisionomia iluminista do homme civilisé e mantém um corte epistemológico entre as esferas da moral e do direito.

\section{Kant ea Revolução Francesa}

A posição de Kant (1724-1804), perante o confronto entre a força instituída e os meios violentos de sua superação, orienta-se na 
figura da individualidade moral. Ela é coerente com sua concepção de autonomia. 0 filósofo escreve: "U ma revolução poderá talvez trazer a queda do despotismo pessoal ou da opressão ávida de lucros ou de domínios, porém nunca trará a verdadeira reforma no modo de pensar". A objeção kantiana à revolução é de caráter moral, pois "apenas novos preconceitos, assim como os velhos, servirão como corrente de cabresto para conduzir a grande massa destituída de pensamento".2

Ressalta à vista que Kant parte de uma constelação personalizada, à moda da filosofia política da tradição, quando se quer saber se há ou não um bom governante para o exercício do poder à disposição. No caso assinalado por Kant, trata-se de romper as cadeias de um déspota, avarento por vantagens materiais, desprovido de integridade moral. Realizado com força, esse rompimento apenas substitui velhos por novos preconceitos, porquanto se atém ao círculo dos círculos iniciados por um tutor que pôs sua canga sobre determinado aglomerado humano. Para a arraia miúda não se altera nada, com exceção dos personagens tutores. A revolução é por ora avaliada por Kant sem nenhum senso teórico, ${ }^{3}$ com base nos papéis predicados aos indivíduos que a fazem. Por serem realizações no plano do fáctico, o filósofo Ihes contrapõeum princípio normativo-racional, denominado Reform der D enkungsart (reforma no modo de pensar).

Tal reforma, a única que sustenta o progresso na história, está justificada pelo fato de os homens haverem sido alforriados pela natureza. A razão não é, para Kant, senhora de suas origens ou, como Schopenhauer (1788-1860) diria, não pode permitir a ilusão de achar que foi ela quem pôso primeiro ovo, do qual tudo proveio. Esse rompante de criatividade não responde à pergunta que quer saber o que veio primeiro, a galinha ou o ovo. Se o homem deve sua liberdade à natureza, não sendo seu próprio criador, a tarefa da razão consiste em mantêlo livre do preconceito de achar que a liberdade não é suficiente para resolver os problemas que o ser livre por natureza Ihe impõe. A moral kantiana prescreve garantir 
a autonomia da razão pelo reconhecimento de seus limites; vale dizer, pela aceitação racional de que o homem não é autor das condições de sua liberdade. A grande massa (der grosseH aufen), como Kant insiste, está bem-servida com revoluções. Elas Ihe dão tutores, sem os quais seria difícil viver, e se consola em ver que os novos tutores estão, eles próprios, sob o mesmo jugo que os antigos lhe haviam imposto. 0 Esclarecimento fica, portanto, nas mãos dos Selbstdenkenden. A penas eles são promotores do Esclarecimento, somente neles a razão esclarecida encontra suportes históricos que não a passam para trás - quer dizer, que não fazem com que a primeira natureza, dadivosa, se transforme em natureza opressora. Para Kant, homens esclarecidos fazem bem em não fazer revoluções. Eles devem estar comprometidos com a reforma do pensamento.

Na segunda seção de 0 conflito dasfaculdades (1798), ao abordar as relações entre filosofia e direito, Kant posiciona-se diante de "um acontecimento de nosso tempo" e chega a conclusões que alteram posicionamentos anteriores consagrados. A passagem insere-se no renovado questionamento: o gênero humano encontra-se em constante progresso? A questão éren ovada porque já fora abordada em "Sobre a expressão corrente: isto pode ser correto na teoria, mas não vale na prática" (1793), assim como no primeiro suplemento de A paz perpétua (1795). ${ }^{4}$ Embora o filósofo mantenha a primazia do ponto de vista moral, o texto introduz argumentos até então ignorados no horizonte da moralidade kantiana:

Este acontecimento não consta, digamos, de ações ou crimes importantes, cometidos pelos homens [...]. N ão, nada disso. É simplesmente o modo de pensar dos espectadores que se trai publicamente neste jogo de grandes transformações, [...] e demonstra assim (por causa da universalidade) um caráter do gênero humano no seu conjunto e, ao mesmo tempo (por causa do desprendimento), um caráter moral [...] que não só permite esperar a progressão para o melhor, mas inclusive já constitui tal futuro progressivo, na medida em que se pode já agora obter o poder para tal. ${ }^{5}$ 
0 primado da moral continua de pé, a despeito do jogo de interesses imanente ao processo revolucionário. Por sua universalidade, o ocorrido demonstra um caráter moral, pelo menos na disposição que denota. 0 visor moral não está, porém, mais fixado em atores, em ações ou crimes de indivíduos. 0 fato de assim parecer devese ao modo de os espectadores entenderem o que está ocorrendo. A D enkungsart deixa de ser privilégio de um punhado de sábios, para tornar-se o modo de ser de multidões. 0 bjetivamente, o acontecimento não só aponta com maior ou menor segurança para o futuro, mas já é ele próprio a progressão para o melhor. Kant pondera: "A revolução [...] pode ter êxito ou fracassar, poder estar repleta de miséria e de atrocidades, de modo que um homem ponderado, se pudesse esperar, [...] jamais resolveria fazer 0 experimento com semelhantes custos". M esmo sem poder apresentar um argumento contundente, o filósofo apostrofa moralmente enfático: "Essa revolução, afirmo, todavia, depara nos ânimos de todos os espectadores [...] com uma participação segundo o desejo que raia à fronteira do entusiasmo, cuja externação [...] não pode ter nenhuma outra causa senão uma disposição moral no gênero humano". ${ }^{6}$

Sob perspectiva moral, o evento revolucionário equivale, para os espectadores, a um signo histórico (G eschichtszeichen) daquilo que os homens possuem de melhor. Essesigno tem no público espectador seu verdadeiro interpretante, cuja solidariedade de ânimo com a humanidade, ${ }^{7}$ gen eralizada e desinteressada, determina culturalmente 0 que, no âmbito da razão prática, somente 0 respeito pela lei moral é capaz de promover e fica à mão dos homens de boa vontade. Como tal, nada mais que a universalidade e 0 altruísmo da simpatia pelos acontecimentos, atestados pelo público exterior, credenciam a R evolução Francesa como garantia atual de progresso do gênero humano. ${ }^{8}$

Para Kant, a G rande Revolução não é um fenômeno coletivo que leve indivíduos históricos de roldão e os consuma moralmente no fanatismo político. Indiciadora de futuro, ela marca o takeoff de 
uma nova ordem teórica, ou seja, o direito de um povo de não ter de ser impedido por outros poderes, ao dar-se uma constituição civil. ${ }^{9} 0$ imperativo prático a priori persiste, o princípio do direito não o substitui nem o limita, mas torna-se o seu aliado. Enquanto 0 primeiro reporta-se à autoconsciência da existência - a duração de cada homem como ser vivente - , o segundo abarca o devir, inconcebível sem alteridade, ou à revelia do que o filósofo chama de gênero humano. Kant raciocina: "Não numa porção sempre crescente de moralidadena disposi ção de ânimo, mas na multiplicação de produtos de sua legalidade [... ] poder-seá situar o ganho (o resultado) do cultivo do mesmo para o melhor". ${ }^{10}$

0 porvir ético da espécieé, para Kant, tributário de princípios internos de direito (innere Rechtsprinzipien), de acordo com os quais o fenômeno da Revolução Francesa - na ordem do tempo uma ocorrência casual - conjuga natureza e liberdade, um efeito que "nenhum político teria extraído do curso atual das coisas". 11 Somente através dele, do ordenamento racional-jurídico, o gênero humano pode vislumbrar o progresso. 0 fato de a razão prática determinar ipso facto a vontade não é mais visto como único poder racional de regulação universal. A idéia de aglutinar a multiplicidade do querer humano pela legalização do agir exterior dos homens, a qual não exige autocoerção, mas sim reciprocidade coercitiva sob o autodomínio da lei (Selbstherrschaft des G esetzes), é "a norma eterna para qualquer constituição civil e afasta toda guerra". ${ }^{12}$ Esta última é o empecilho por excelência do que é moral.

0 regime normativo do direito, cujo alcance é a cultura humana em seu todo, leva Kant a inverter o curso das coisas ( $G$ ang der D inge), postulando que o progresso moral não se dá "de baixo para cima, mas de cima para baixo". 0 outrora leitor entusiasta do E mílio (1762) não acredita mais que por meio da formação da juventude, pela instrução no lar e nas escolas, numa escala intelectual e moral ascendente, reforçada pelo ensino religioso, seja possível chegar "a não só educar bons cidadãos, mas educar para o bem 0 que ainda pode progredir e conservar-se". Tal plano, afiança Kant, 
"dificilmente permite esperar o êxito almejado". ${ }^{13}$ Em suma, égraças à revolução que o justo/injusto está sob a proteção do conceito moral de direito e não mais sob a tutela da educação caseira, aos cuidados da instrução escolar ou da formação religiosa.

A maneira como Kant participa da revolução de um povo pleno de espírito alça sua doutrina de direito a uma idéia da razão. À semel hança do que está de imediato à disposição da razão teórica e da razão prática, die Begebenheit da Grande Revolução, torna possível conhecer a priori as condições sob as quais seres dotados de poder para arbitrar impulsos e inclinações agem racionalmente. Kant formula as condições a priori como segue: "C aso se pudesse atribuir ao homem uma vontade inata e invariavelmente boa, embora limitada, ele poderia progn osticar com certeza a progressão de sua espécie para o melhor, porque se trataria de um evento que ele mesmo pode realizar". ${ }^{14} \mathrm{D}$ epois de passar para o plano da experiência e afirmar que deve haver um acontecimento que remeta à constituição eà faculdade por parte do gênero humano de ser causa do progresso e seu autor, Kant constata: "a partir de uma causa dada pode-se predizer um evento como efeito, quando ocorrem circunstâncias que concorram com ele". Embora se possa em termos gerais saber, "como no cálculo de probabilidades no jogo", que alguma vez circunstâncias devam configurar ocorrências, é impossível determinar "se tal acontecimento ocorrerá em minha vida e se farei a experiência disso", confirmando a possível predição. N ecessário é, pois, "procurar um evento que aponte para o estar-aí de tal causa e igualmente para 0 ato de sua causalidade no gênero humano, ainda que indeterminado quanto ao tempo". Dessa existência a investigar seria possível inferir, como conseqüência inelutável, a progressão e, "assim, poder-seia demonstrar a tendência do gênero humano no seu todo, isto é, não conforme os indivíduos [...], mas considerado segundo o modo como se encontra dividido em povos e Estados sobre o planeta". ${ }^{15}$

Para o filósofo crítico, a revolução dos franceses legitima a reivindicação moral da razão de que a espécie humana está a 
caminho, como sempre esteve, de um futuro ético. Vale dizer, a tipicidade maior da lei suprema do direito racional é, em Kant, a publicidade legalizadora da Revolução Francesa.

Após discorrer sobre a concepção racional de direito e a divisão de poderes no Estado constitucional, Kant expõe as eficácias jurídicas que derivam da união civil e desenvolve sua teoria de legal ização estatal. Por mais rel evantes que sejam as diferenças entre direito racional e constitucionalismo moderno, ${ }^{16}$ no mais tardar na observação " $A$ " do direito público kantiano, fica clara a incompatibilidade entre o regime crítico, de um lado, e o regime dialético ou axiológico, de outro, no tratamento dado à crux do direito - a coerção. Tanto o objetivismo valorativo quanto o substancialismo ético concebem exigências deontológicas como portadoras de um minus em determinação conceitual, destinadas que são ao superdimensionamento filosófico pela ordem axiológica material ou por uma positividade ética integradora.

Se a filosofia política de Hegel pode ser vista como o mais engenhoso projeto de superação filosófica da coerção na coexistência humana, o republicanismo kantiano a toma por elemento-chave da idéia de direito. A concepção hegeliana de eticidade, dos chamados "poderes éticos que regem a vida dos indivíduos", ${ }^{17}$ da qual 0 Estado monárquico-constitucional éa realidade efetiva, ${ }^{18}$ não coaduna com a legitimação jurídica do poder coercitivo ratificada por Kant in statu civile. A concepção de que ao princípio estatal moderno assistem "este vigor e esta profundidade prodigiosos de deixar 0 princípio da subjetividade plenificar-se até o extremo autônomo da particularidade pessoal e, ao mesmo tempo, de reconduzi to à unidade substancial [...]",19 fere a postura de Kant, para quem o pactum subiectionis civilis é uma idéia subsistindo como princípio prático da razão, seja qual for a origem do poder legiferante em atuação. ${ }^{20}$

Para Kant, princípios de direito não atestam um determinismo inferior, passíveis segundo N. Hartmann (1882-1950) de serem submetidos a uma determinação superior na esfera axiológica, tampouco são apêndices abstratos do imperativo categórico, carentes 
conforme Hegel de uma efetiva realização no Estado ético, mas obedecem sim a uma arquitetura racional própria.

A doutrina do direito não exige que o dever jurídico seja motivo da ação justa, diferentemente da ética kantiana, na qual a ação moral só pode ser engendrada pelo fato de ter a lei moral por princípio afetivo, designado respeito. Para Kant, o direito não é uma moral menos rigorosa e tampouco uma maneira oportuna de dispensar a moralidade. Se assim fosse, a doutrina kantiana do direito ou seria descartável ou poderia ter revidado o primado da moral. Ambas as hipóteses excluiriam a limine a possibilidade de uma teoria crítica do Estado no horizonte da filosofia política kantiana. ${ }^{21}$

Kant também não deduza legitimação da coerção legal a partir de um fato histórico, como garantia do exercício exterior da liberdade, inata para ele a todo ser humano, mas da idéia de regular relações humanas sob o império de leis externas, sejam elasnaturais ou positivadas. Toda tentativa de qualificar ética ou val orativamente a origem da força suprema, questionando o seu início violento, é rechaçada por Kant. 0 ius tem, para o filósofo, a estatura de um princípio formal de ação, distinto da ética que prescreve leis para máximas subjetivas e, como tal, não é imune à objetividade das normas jurídicas na esfera intersubjetiva recíproca. Confrontados com a obrigação de ater-se às regras do direito, os deveres éticos são, enquanto deveres de virtude, ${ }^{22}$ imperfeitos, não obstante tenham um raio de ação mais amplo que as obrigações advindas do direito. ${ }^{23}$ Por maior que seja o mérito de quem respeita as leis positivas do direito, sua virtude não torna supérflua a normatividade jurídica mas sim a pressupõe. Querer conservar uma unidade substancial entre os extremos da independência de cada homem em relação a seu semelhante não vai ao encontro, mas se afasta da idéia de que a coerção é imanente a qualquer obrigação, seja ela auto-imposta ou exercida por outrem.

O Estado é, para Kant, uma construção jurídica, ao passo que $\mathrm{H}$ egel o concebe como grandeza cognitiva, condensado eticamente 
pelo espírito objetivo. A objeção hegeliana mais séria ao contrato social rousseauniano não afeta o livrearbítrio dos contratantes, mas incide sobre as conseqüências que o contratual ismo político tem no âmbito do entendimento, segundo $\mathrm{H}$ egel, "destruidoras do divino em si e por si e da sua autoridade e majestade absolutas". ${ }^{24}$ M esmo onde se confronta com o tiranicídio, na forma do justiciamento do monarca, K ant mantém a duras penas a argumentação jurídica e se abstém de dial etizar a origem do direito com uma noção de eticidade que a pudesse legitimar para todo sempre. Para Kant, a submissão incondicional da vontade popular a uma vontade soberana é Tat (fato). Ela só podeinstalar-se pelo domínio da força, fundamentando assim, primeiramente, um direito público. Conceder um direito à resistência à tal plenitude de poder seria contraditório, segundo Kant, pois anularia a instância que determina o que é para ser publicamente de direito e o que não é por direito. Kant arremata: "E esse princípio já está contido a priori na idéia de uma constituição de Estado, isto é, em um conceito da razão prática, ao qual, embora não possa ser atribuído adequadamente nenhum exemplo na experiência, também nenhuma norma deve contradizer". ${ }^{25}$

Kant concebe, na forma do sollen analítico, o postulado do direito público a partir do direito privado, provisório no estado natural, mas o estabelece na forma sintética do müssen, de modo que a cada um, em caso de conflito acerca do meu e do teu, deve ser permitido constranger seu semelhante a "aderir com ele a uma constituição civil", uma vez que somente "em um estado civil pode haver um meu e teu exterior". ${ }^{26}$ U ma coerção legal só pode ser imposta com base numa lei positiva externa e com matriz impositiva. $\mathrm{N}$ o estado de natureza os homens podem tentar conseguir uns dos outros um agir de acordo com a razão, mas nunca terão a garantia a priori de que al guém irá ater-se àquilo que a razão Ihe prescreve. A coerção recíproca universal implica, para Kant, que se desista de procurar convencer os outros do que é justo ou injusto e se fique limitado a regular a relação entre arbítrios, isto é, sem nenhum componente ético ou intencional, exigindo apenas a ordenação 
exterior dos homens entre si. I sso só é possível, segundo Kant, com a liberdade que assiste a cada homem em virtude de sua humanidade, ${ }^{27}$ de modo que o direito de coagir alguém é igual à autorização que esse alguém possui para coibir um uso de liberdade que impede a construção de um conceito de lei universal, ou seja, "sua apresentação em uma pura intuição a priori, de acordo com a anal ogia da possibilidade de movimentos livres dos corpos atuarem sob a lei da igualdade da reação e contra-reação". Materialmente, os homens não têm assim, para Kant, outras obrigações no direito público a não ser aquelas que o direito privado Ihes prescreve. 0 que caracteriza as leis do direito público é sua forma jurídica nos termos de uma constituição, "em relação à qual essas leis têm de ser necessariamente pensadas como públicas". ${ }^{28}$

0 caminho que leva da moral ao direito passa, em Kant, pela faculdade inata de cada homem fazer uso de sua liberdade. A construção racional da vinculação jurídica supõe que os indivíduos não alienam seu direito subjetivo, quando se submetem reciprocamente a uma constituição republicana. Essa é a originalidade perante R ousseau, e explica por que Kant não recorre ao Législateur no limiar da República, o homem capaz de fazer com que "um povo que nasça possa degustar as sãs máximas da política e seguir as regras fundamentais da razão do Estado". De resto, Kant silencia de todo sobre a Science du Législateur, que habilita, em Rousseau, a "persuader sans convaincre". ${ }^{29}$ A filosofia política kantiana também não reserva lugar à presença integradora do funcionário prussiano, registrada por $\mathrm{H}$ egel no epicentro político do espírito objetivo. Tampouco é viável, sob visor kantiano, a substituição dos membros da classe média hegelian ${ }^{30}$ pela figura paradigmática do revolucionário esclarecido, uma espécie de funcionário público não-concursado, com a filosofia na cabeça e o proletariado no coração. R econciliando homme e citoyen, o funcionário público hegeliano assegura objetividade política ao espírito dialético e, com a figura do revolucionário Marx (1818-1883), reintegra socialmente o que a dialética do bourgeois dividira no sistema de carências do espírito 
objetivo. Integrar ética e direito, suprassumindo o último na primeira, não chega a ser uma idéia reguladora em Kant.

\section{Mord eDireito Racional}

Segundo Kant, o uso público da razão termina onde inicia a doutrinação. N enhum existente dispõe, para Kant, sobre a virtualidade de engendrar por si o que é normativo. Trata-se de fazer uso público da razão, enão de saber com quantos sábios podese contar ou quantos deles estão à disposição para o uso público da razão. Descartada está também, em Kant, a possibilidade de institucionalizar o uso público da razão em um órgão administrativo ou de assegurá-lo na forma de uma instância ou personalidade jurídica. U m indicativo de queKant não faz do estamento dos sábios uma hipóstase do uso público da razão éo fato de o militar, o ministro religioso e o próprio contribuinte serem eruditos, desde que as condições do uso público da razão estejam dadas e eles se atenham a elas, ao agirem como sábios diante do grande público do mundo letrado. ${ }^{31}$ Para que isso aconteça, de acordo com o texto "O que é Esclarecimento?" (1784), nada é exigido a não ser liberdade.

D ois anos após, em "Q uesignifica orientar-se no pensamento" (1786), Kant elenca três obstáculos que contrariam o uso público da razão: a coerção civil, a coação da consciência e, finalmente, a máxima do uso sem lei da razão. A argumentação dirige-se contra as pretensões do gênio, cuja atuação como sábio ocorre sob a "máxima invalidade de uma razão supremamente legisladora". Tal atitude "nós, homens comuns", diz Kant, "chamamos de exaltação sentimental (Schwärmerei), e os favoritos da benevolente natureza denominam iluminação (E rleuchtung)". 0 filósofo conclui dizendo que desse modo advém a "total subordinação da razão aos fatos, isto é, a superstição (A berglaube)". 32

Do exposto se segue que o uso público da razão, seja pelo erudito comum, seja pelo sábio ocasional (militar, sacerdote, 
contribuinte), deve estar autolimitado pela crítica da razão nos moldes de uma legislação racional suprema. Para coibir o abuso de um uso público indevido da razão, na figura do sábio de qualquer espécie, esse deve omitir-se de fazer um uso desenfreado da razão. C omo disse Kant, tal emprego leva invariavelmente à superstição.

Pela C rítica da razão prática (1788) sabemos que há uma razão não-desenfreada em exercício. A razão prática não necessita, como o interesse especulativo da razão teórica, ${ }^{33}$ de ser criticada para evitar que exorbite indevidamente suasfunções, abandonando o domínio da experiência sensível. A segunda C rítica, no prefácio, não submete a faculdade pura à crítica, "a fim de ver se a razão não se ultrapassa, ao presumir simplesmente uma faculdade desse gênero (como sucede com a razão especulativa)". "Não se trata, conseqüentemente", assevera Kant, "de compor uma crítica da razão pura prática, mas tão-somente de elaborar uma crítica da razão prática". A pós constatar que a razão pura, desde que esteja provado que haja uma tal, não necessita de crítica de modo al gum, uma vez que ela própria contém o critério de orientação para a crítica de todo o seu uso, Kant estabelece que "a crítica da razão prática tem de modo geral, por conseguinte, a incumbência de sustar a presunção da razão empiricamente condicionada de fornecer exclusivamente, ela somente, o princípio da determinação da vontade". Ao invés do uso da razão pura - o único uso imanente que há, desde que tal uso esteja assegurado - , o uso empírico-condicionado da razão, reivindicando para si o senhorio exclusivo, é, para Kant, "transcendente e se expressa em pretensões e mandamentos que vão totalmente além de seu domínio". Kant conclui o raciocínio, indicando, na introdução, que isso constitui precisamente "a relação inversa do que pôde ser dito da razão pura em uso especulativo". ${ }^{34}$

A incumbência crítica da razão prática não se refere à razão pura, mas exclusivamente ao pretenso mando racional que a razão empírica exerce sobre as determinações da vontade. A segunda Crítica mostra que a razão pura é prática pelo fato de ter imanentementeà disposi ção um dado sem o qual a primeira $C$ rítica operaria 
no vazio - a sensibilidade. A incumbência crítica da razão prática não tem a ver com a razão pura, mas exclusivamente com pretensões racionais abusivas, alheias ao domínio experiencial da razão pura prática, por operarem erroneamente com sensibilidades cognitivas no âmbito da moralidade, presentes em qualquer tipo de intuição edificante para o senso moral comum.

O uso público-esclarecido da razão, pelo respectivo sábio, está de acordo com o que a C rítica da razão prática elabora. Ela impede a presunção da razão, empiricamente situada, de querer determinar sozinha o agir esclarecido do agente erudito, contrariando o uso crítico imanente da razão pura. Q uando isso não acontece, no caso de sábios que, como donos da verdade, fazem aparentemente uso público da razão, a constelação bate de frente com o que está garantido pelo uso da razão pura, provocando uma inversão da A ufklärung. U m uso público da razão, que tão-somente na aparência está de acordo com a razão prática, faz dos ditames da razão pura um contra-senso, vale dizer, justifica empiricamente o que a C rítica da razão pura evidenciou como constituindo um uso racional sem cobertura crítica. Para o gênio, como figura tipológica de um uso público indevido da razão, Kant constata: "A conseqüência desse fato é naturalmente que, quando a razão não quer se submeter à lei que ela se dá a si mesma, ela tem de se curvar ao jugo das leis que um outro Ihe dá". D epois de asseverar que, à revelia de qualquer lei, também a maior asneira (U nsinn) não tem condições de manter o jogo por muito tempo, o filósofo infere uma razão prática que pauta o seu uso pela declarada ausência de lei no pensamento. Kant escreve: "A liberdade de pensar fica, em última análise, perdida e como a culpa não cabe a al guma infelicidade, mas a uma verdadeira arrogância, [a liberdade] será, no sentido próprio da palavra, jogada fora levianamente". 35

Essa série de concatenações argumentativas afigura-se, à primeira vista, redundante eaporética. Redundante, porqueo gênio, mesmo passando faticamente por cima dos limites da razão, não tem sucesso, por acabar rapidamente nos limites impostos por um 
terceiro. G ênios deixariam de ser à medida que os há. Sua atuação seria aparente apenas momentaneamente, não mais caracterizando o risco permanente de uma perda leviana da crítica racional. A porética, porque a solução apresentada não dispensa a coerção civil que, como Kant indica, é o que em primeiro lugar obstaculiza a liberdade de pensar. $\mathrm{N}$ a exata medida em quea coerção de tercei ros encaminha o gênio de volta aos limites imanentes ao uso da pura razão, ela o impede de pensar de acordo com o que a razão prática postula como conditio sine qua non para um uso público da razão. De qualquer forma, Kant constata resignativo: "A liberdade de pensar é a única jóia (K leinod) que ainda nos resta, apesar de todas as cargas civis, e, exclusivamente graças à qual, pode ainda ser produzido um remédio contra todas os males de tal situação". ${ }^{36}$

$\mathrm{N}$ a verdade, o redundante e o aporético marcam o ponto de partida de uma concepção de homem que se afirma autônomo na medida em que assume problemas oriundos daquilo que lhe é heteronômico. No artigo sobre o Esclarecimento, a contraposição ocorre ainda sob o eixo de uma representatividade coletiva: de um lado, o mob desorientado e moral mente amorfo e, de outro, o grupo dos happy fews em torno dos holofotes da razão. N a Fundamentação à metafísica dos costumes (1785), os termos continuam sendo usados em sentido antinômico corrente, designando a oposição entre uma vontade qualificada, por leis dadas a si mesma, e uma vontade desqualificada pelasleis que lhe são dadas, abdicando da autonomia de ditar regras de jogo para suas ações. Kant recorre à teoria dos dois reinos, liberdade e natureza, para distinguir o agir autônomo das reações meramente heteronômicas. Já no texto de 1786, “Q ue significa orientar-se no pensamento?" , a merajustaposição conceitual fica inerte na medula da razão, anestesiada pelo gênio no ápice elitista dos iluminados esclarecidos. No entanto, a figura do Schwärmer (fanático sentimental) pode ainda ser confundida com uma idiossincrasia intelectual, facilmente desmascarada sob o ponto de vista da razão. Somente na segunda $C$ rítica, voltando a referir-se à Schwärmerei, Kant a enquadra nos vetores doutrinários de uma 
moralidade estrita e estabelece a fronteira intransponível entre fanatismo moral e respeito perante a lei moral. ${ }^{37}$

A presença do gênio assinala menos o caráter exótico de uma racionalidade fora dos trilhos do que a fisionomia distorcida de um anthropós superior desprovido de moralidade. 0 problema antropológico pode ser rastreado desde as páginas finais da primeira C rítica, quando Kant reconhece que a filosofia não consiste apenas em propedêutica, chamada crítica, mas também na exposição de todo conhecimento filosófico, tanto o verdadeiro quanto 0 aparente, o que se chama metafísica. 0 problema torna-se agudo no momento em que a moral esclarecida necessita de um critério demarcatório para evitar que, em nome da genialidade, a superstição seja legitimada, ficando o mundo à mercê de uma imoralidade iluminada. Talvez seja essa a razão por que Foucault (1926-1984) intui, no artigo acerca do Esclarecimento e no texto sobre a $G$ rande R evolução, um senso kantiano do presente racional, detectando neles a possibilidade de uma ontologia de nós mesmos, como ontologie del'actualité. A opção filosófica atualizada pela ontologie de nous-même, apostrofada por Foucault, remete a uma concepção antropológica centrada na questão da autonomia e da heteronomia, constituintes do homem como ser histórico.

$\mathrm{Na}$ C rítica da razão prática temos a constelação da vontade humana, em contraste com uma vontade santa. De acordo com tal delimitação, o complexo autonomia-heteronomia é tipicamente humano, caracterizado pela faculdade de acionar máximas conflitantes. A lei moral não impera espontaneamente no homem, mas, única e exclusivamente, graças a um sentimento causado pelo imperativo categórico, a fórmula da lei moral. ${ }^{38}$ I moral seria uma teoria de personalidade que dogmatizasse a necessidade como categoria moral ou explicasse a atuação da vontade com meros argumentos, deixando indistintos lei moral e sentimento moral. A vontade dos humanos obedece ao imperativo incondicional da lei moral por respeito, quer dizer, por uma motivação sensível. A eliminação dessa conjunção obrigatória faria dos homens seres 
desumanos, porquanto condená-los-ia a uma idealidade ontológica impossível de ser exercida ou às experiências da dor e do prazer sem autoenvolvimento afetivo.

$\mathrm{Na}$ M etafísica dos costumes (1797) temos a configuração do arbítrio humano contrastando com 0 arbítrio animal. Enquanto esse é regido por estímulos, incapazes de serem constrangidos volitivamente, aquele pode, não obstante afetado por impulsos, ser determinado pela vontade. A vontade não pode ser designada livre ou não-tivre, no sentido de fazer ou deixar de fazer, mas é por definição autônoma ou heterônoma. Ela não se volta às ações, mas diretamente à legislação para a máxima das ações. A o legislar sobre o agir a que se propõe, ela é incapaz de ser constrangida pelas máximas desta ou daquela ação. Sob este aspecto, "somente 0 arbítrio", dizKant, "pode, portanto, ser chamado livre". ${ }^{39}$ De acordo com a definição, uma vontade santa, incapaz de se dar uma máxima que não seja ipso facto lei, não é livre, muito embora moral por constituição. Ela desconhece a obrigatoriedade do dever, como 0 animal ignora a força da lei.

A metafísica kantiana revela o senso telúrico de uma ciência dos primeiros princípios do conhecimento humano. "A metafísica dos costumes", indica Kant, "não pode ser fundada sobre a antropologia, mas pode ser-the aplicada". ${ }^{40} \mathrm{~K}$ ant aplica na doutrina do direito os princípios da filosofia moral a uma legislação exterior e aplica na doutrina da virtude os mesmos princípios a uma legislação interna. No que concerne ao direito, o critério moral para o justo e 0 injusto assegura a priori que a tarefa do direito seja concebida de maneira consistente. $D$ a tarefa do direito são obtidas as condições de aplicação. A totalidade delas perfaz um fato empírico de caráter genérico-elementar, a saber: 0 estar lado a lado de seres racionais, compartilhando o mesmo mundo, correspondendo à construção de um espaço preenchido por forças. Tal é, para Kant, a condição geral para qualquer legislação externa, independente das diversas feições que ela adquire em povos e culturas diferentes. 
0 conceito moral de direito, adquirido mediante o critério universal de legislação da razão pura prática, tem a seguinte formulação: "O direito é, pois, o conjunto das condições, sob as quais 0 arbítrio de um pode unificar-se com 0 arbítrio de outro de acordo com uma lei universal da liberdade" ${ }^{41} 0$ bjeto das condições normativo-universais do direito não é a liberdade da vontade autônoma, ao ser lei para si mesma, mas sim o arbítrio como liberdade de ação independente do arbítrio de outro agir ou não agir. A objetividade do conceito moral de direito, contida na fórmula, não é deduzida da autonomia da vontade e tampouco é pressuposta como liberdade natural distinta in re da liberdade moral. Admitir aqui uma bem-sucedida dedução da liberdade implica reconhecer que Kant teve sucesso, na Fundamentação à metafísica dos costumes, em deduzir da lei moral a autonomia da vontade, uma vez que a segunda Crítica não passaria de um mal-entendido. Admitir, por outro lado, um conceito moral empírico de direito implica submeter a liberdade de ação a critérios normativos objetivamente anteriores à liberdade determinada de maneira jurídica, tais como o bemestar próprio ealheio, com a conseqüência de que a segunda Crítica estaria revidada pelo discernimento de uma boa e má liberdade.

A mbas as alternativas positivam o conceito de lei e racionalizam o conceito de liberdade à revelia da razão pura prática, de modo que a liberdade se converte em ratio cognoscendi da lei moral e a norma jurídica torna-se ratio essendi da liberdade. Para Kant, ao contrário, a autonomia da vontade só é racional como ratio cognoscendi de minha inviolabilidade pessoal porque posso obedecer a uma lei não-natural por respeito a ela. 0 arbítrio, por sua vez, só éracional como ratio cognoscendi de minha liberdade de ação porque tenho a capacidade de fazer e deixar de fazer 0 que quero. 0 livrearbítrio encontra os seus limites morais no imperativo categórico (a fórmula da liberdade positiva), na medida em que a lei moral pode ser invocada pelos demais como uma lei universal (a fórmula da liberdade negativa). 0 fato de a razão aplicar ela mesma, 
coativamente, a lei moral significa que o homem não saberá jamais se é ou não é livre, pois lá onde a razão é mais prática ela é também mais sensivelmente moral.

0 direito racional trata, em Kant, do ordenamento externo dos humanos entre si. As normas estatutárias não superam, pela potência cognitiva do saber, e tampouco integram, na forma de uma positividade ética, o que caracteriza a autonomia e a heteronomia no campo estrito da moralidade kantiana. Embora as instâncias legisladoras da ética e do direito não coincidam quanto aos motivos, ${ }^{42}$ a força vinculadora de ambas é de caráter moral. U ma lei só pode ser vinculante ao eliminar o arbitrário do agir humano, seja interna ou externamente. Sob este aspecto, 0 complexo-chave da moral kantiana, autonomia-heteronomia, não permite considerar a moralidade como o domínio da primeira e 0 direito como a esfera da segunda. ${ }^{43}$

Tal posição iria postular uma dupla legislação de razão prática, o que constitui uma contraditio in adjecto, ou seja, na suposta legislação jurídica da razão prática, a idéia do dever teria de ser motivo do dever - por tratar-se de uma legislação da razão prática - e simultaneamente não deveria ser o motivo do dever - por tratar-se de legislação jurídica. Por mais oscilantes, imbricadas e superpostas que sejam as relações entre moral e direito, em Kant, ${ }^{44}$ a teoria kantiana de uma individualidade esclarecida supõe tanto a autonomia quanto a heteronomia como condição de moralidade. N eutralizar de uma vez por todas a heteronomia, exilando-a para a área do direito, eliminaria a faculdade da razão de ser prática, não à moda santa, mas à maneira mundano-racional. 0 u seja, o fato de o homem ser afetado por impulsos e não estar livre de inclinações e estímulos é condição de possibilidade de ações unicamente motivadas por dever ao princípio da vontade.

Resolver a problemática da autonomia e da heteronomia, confiando o indivíduo autônomo à moralidade e o indivíduo heteronômico à racional idadejurídica, eliminaria a questão de saber sob quais condições da conditio humana se instala, em Kant, a 
necessidade de haver direito. ${ }^{45}$ Para o filósofo, o estatuto metafísico da personalidade moral delimita-se, por um lado, pela vontade de um ente sagrado e, por outro, pelo arbitrium brutum. A primeira não necessita do imperativo moral, e ao segundo não fazem falta leis estatutárias. A autonomia do homem não é santa, para Kant, assim como a vontade heteronômica da personalidade moral não Ihe é animalesca, ao ser determinada por uma força motivacional condicionada empiricamente. Em suma, santidades e bichos são constitucionalmente incapazes de ser esclarecidos.

$\mathrm{Na}$ C rítica da faculdade do juízo (1790), Kant identifica, no contexto da crítica do gosto, a logomarca da A ufklärung com as máximas do entendimento humano comum: "Primeiro, pensar por si; segundo, pensar no lugar de qualquer outro; terceiro, pensar sempre de acordo consigo próprio", e define E sclarecimento como a libertação da superstição. ${ }^{46}$ Tal definição caracteriza 0 arco crítico em seu ponto extremo de distensão conceitual. A rigor, o Esclarecimento consiste, para Kant, em uma tarefa "simplesmente negativa", vale dizer, um negativo sem correspondente positivo, al go assim como o lema mefistofélico da M odernidade. ${ }^{47}$

No extremo oposto à atuação do gênio, do sectário ou do iluminado, Kant localiza um outro tipo de uso indevido da razão e, extensivamente, de doutrinação e de inversão da A ufklärung. A constelação que à primeira vista se impõe é a de um imperativo categórico negativo, a idéia de uma máxima universal izável à revelia de todo e qualquer impulso sensível, unicamente com base na motivação demoníaca de fazer o mal pelo mal. No âmbito da moralidade, à figura de Satanás falta, porém, fisionomia em Kant. 0 gênio do mal não exerce, para o filósofo, o papel que a religião reserva aos demônios na história dos homens. $\mathrm{Na}$ segunda $\mathrm{C}$ rítica, mesmo o Bösewichter (celerado de nascença) não consegue manterse infenso à moralidade. Segundo Kant, não há educação capaz de corromper de tal forma os homens, a ponto de torná-los maus, desprovidos de sensibilidade, por assim dizer, heteronômicos por unívoca definição racional. ${ }^{48}$ 
Tão-somentena $\mathrm{D}$ outrina do $\mathrm{D}$ ireito, ao abordar o justiciamento de Carlos I e Luís XVI, Kant detém-se na silhueta do Ä usserst-Bösen (do mal extremado/ radical) e reconhece que a maldade expressa, ainda que imprópria aos humanos, não deve ser ignorada em um sistema da moral. ${ }^{49}$ Enquanto simples idéia do que é mau em extremo (blosse I dee des Äusserst-Bösen), a figuração do demoníaco no início da ordem jurídica não tem caráter de realidade, e muito menos constitui postulação moral. Kant valese dela, por um lado, para salvaguardar a convicção de, também na pior injustiça, a humanidade continuar mantendo viva a idéia do direito, e, por outro lado, para assegurar que a ordenação jurídica vigente, mesmo tendo a violência por origem, mas não por norma, é mais salutar que a ausência de qualquer forma de justiça e está, assim, de acordo com a máxima maior do Esclarecimento, orientada invariavelmente para a autopreservação da razão (Selbsterhaltung der Vernunft). ${ }^{50}$

A posição de Kant, avalizando a legitimidade do direito mediante a racionalização da violência na origem do Estado, faz do filósofo o personagem-chave do direito racional. A caracterização mais incisiva do filósofo, como portador do uso público da razão, encontra-se em 0 conflito das faculdades. Kant escreve: " 0 esclarecimento do povo (Volksaufklärung) é a instrução pública acerca de seus deveres e direitos no tocante ao Estado a que pertence". D epois de aplicar o conceito de público, inerente a tal instrução, a direitos naturais e aos provindos do enten dimento humano usual, Kant constata que os arautos e intérpretes naturais desses direitos no meio do povo "não são os professores oficiais de direito indicados pelo Estado, mas livre-docentes de direito, isto é, os filósofos". Para o Estado, "que só quer reinar (herrschen)", os docentes filósofos são um escândalo por causa da liberdade a que se facultam e, "sob o nome de iluministas, são difamados como gente perigosa para o Estado", ficando assim bloqueado o único caminho que o povo tem para trilhar quando quer ser ouvido - a publicidade. "Dessa maneira", conclui Kant, "a proibição da publicidade impede o progresso do povo, mesmo naquilo queperfaz 
o mínimo de sua reivindicação, a saber, aquilo que concerne a seu direito natural". 51

Para Kant, o filósofo é o aliado natural do sujeito de direito. 0 princípio do direito constitui o correspondente subjetivo do direito objetivo, por autorizar o uso de todas as ações que estão de acordo com o conceito objetivo do direito. Na qualidade de princípio, a autorização subjetiva precede a todas as eventuais iniciativas particulares, de modo que o direito subjetivo constitui 0 reverso da medalha do conceito moral de direito, subsistindo com justiça (mit Recht) antes e independentemente do que é de direito (rechtens). 0 princípio do direito assegura quea qualidade do homem consiste em "ser seu próprio senhor" e, "como direito único e originário, que compete a cada homem em virtude de sua humanidade", 52 faculta a cada ser humano fazer uso de todas as leis, estejam elas ou não fixadas nos códigos. ${ }^{53} \mathrm{C}$ omo tal, o princípio do direito estabelece o padrão de medida moral para toda e qualquer pretensão subjetiva direcionada ao fazer e ao deixar de fazer por parte do indivíduo.

À luz do princípio kantiano do direito, liberdade como exclusivo direito inato significa que cada homem é simultaneamente independentee igual em relação ao arbítrio impositivo de qualquer outro. A limitação e a garantia simultâneas da liberdade de ação, expressas pela fórmula do imperativo categórico do direito - "age externamente de modo que o livre uso de teu arbítrio possa coexistir juntamente com a liberdade de qualquer um segundo uma lei universal" 54 - , constituem um postulado da razão, não possíveis de comprovação senão pelo uso público da razão.

0 efeito vinculante que a lei geral do direito (allgemeines Rechtsgesetz) impõe como justiça intersubjetiva recíproca obriga moralmente, isto é, tem caráter objetivo, razão por que não pode ser exigido deninguém que faça dessa vinculação objetiva o princípio de suas máximas para poder agir a bel-prazer. Se pelo princípio do direito tudo o que é compatível com sua universalidade objetiva também é permitido, todos os homens podem agir à vontade, 
enquanto nenhum deles impede o outro de agir, mesmo que todos sejam indiferentes à liberdade alheia ou desejam cerceá-la reciprocamente em seu íntimo. Tomar o agir justo por máxima, doutrina Kant, "é uma exigência que a ética faz a mim". 55

A obrigatoriedade moral do princípio do direito desonera, em Kant, o homem da obrigação de ter outras máximas em seu agir, além daquelas enunciadas pelo princípio do direito, ou seja, 0 indivíduo não é forçado a prestar contas à liberdade dos outros. Basta que admita que cada semelhante faça uso de seu arbítrio ad libitum. "Quando não há a intenção de ensinar virtude, mas tãosomente expor o que é direito", escreve Kant, "não é permitido e não se deve impor a si mesmo aquela lei geral de direito como motivo de ação". ${ }^{56} 0$ fato de o princípio do direito estar em Kant legitimado pela moral desobriga os titulares do direito do dever de ter de se submeter um a um, reciprocamente, ao conceito moral do direito, pois o princípio do direito contém, ele mesmo, a obrigatoriedade moral que vincula objetivamente o livrearbítrio de todos os homens.

Sendo uma realização do direito objetivo, o princípio subjetivo do direito satisfaz por si, para Kant, à obrigatoriedade moral. "Sem o dizer expressamente", constata H öffe, "o seu conceito [de Kant J. H.] de direito exclui todo direito de caráter e toda bisbilhotice em relação a ele". ${ }^{57} \mathrm{~N}$ a verdade, isso não precisava ser dito. A filosofia crítica descarta de antemão qualquer tipo de direito de intenções, toda forma de puritanismo ou outra proposta similar que substitua a única por Kant reconhecida como instância para o ajuizamento de atos da liberdade interna por uma competência externa, seja ela social, política ou jurídica. ${ }^{58}$ A vesso à moralização do direito, 0 princípio do direito rigorosamente diz respeito a liberdades externas e as configura na forma correspondente a um liberalismo exigente. Em outras palavras, o princípio kantiano do direito exige dos homens que se aceitem natural e reciprocamente como parceiros de direito. 
Visto que nem o conceito moral e tampouco o princípio jurídico da ciência kantiana do direito postulam a existência de um legislador, governo ou tribunal, a quem pudessem ser endereçados, é evidente que Kant considera os filósofos, e não os docentes profissionais de direito do governo, como os portadores da tarefa de ensinar ao povo o que cabe a cada homem por nascimento em matéria de justiça. Ao restringir a justiça à liberdade de ação dos homens, limitada e garantida reciprocamente por direito natural, Kant não está em condição de concorrer com os representantes instruídos do direito positivo e se atém à missão de salvaguardar a publicidade de certas leis que constituem o ius naturae.

0 jurista letrado, Kant o situa na companhia do médico e do teólogo. 0 teólogo busca sua doutrina na Bíblia, o médico na Resolução da M edicina (M edizinalordnung) e o jurista no Direito Provincial Positivo (Landrecht). ${ }^{59} \mathrm{~N}$ enhum dos três faz uso público da razão, mas cada um deles ancora o seu saber em estatutos (Statute), e basta que uma das faculdades a que pertencem "ouse introduzir algo como derivado da razão para já ofender a autoridade do governo [...] eacabe envolta pela faculdade de filosofia, que a despoja impiedosamente de toda brilhante plumagem [...]." 60

Kant investe contra a ação supostamente iluminista dos encarregados de negócios, técnicos e práticos de toda ordem (G eschäftsträger/ -leute/ Werkkundige/ Praktiker), os quais, na condição de dignitários eclesiásticos, funcionários da justiça e médicos nomeados pelo governo, degradam a razão através do mau uso do cargo que Ihes foi confiado, prestando um péssimo serviço ao Esclarecimento. 0 s agentes dessa forma de inversão da A ufklärung buscam, segundo Kant, submeter conflitos de idéias ao "tribunal do povo (ao qual não cabe juízo algum em matéria de instrução científica), fazen do que um conflito teórico deixe de ser uma disputa de eruditos". 0 resultado dessa situação é um "conflito ilegal (gesetzwidrig), em que se expõem doutrinas de acordo com as tendências populares e se espalha a semente da insurreição e das facções, pondo dessa forma o governo em perigo". Tais tribunos da 
plebe que a si próprios constituem, "renunciando ao estado de letrados", Kant os denomina N eologen (neólogos), "cujo nome, detestado e com razão, é muito mal-entendido, se referido a todos os autores de uma inovação nas doutrinas e respectivas formas (de fato, por que é que 0 antigo haveria de ser sempre o melhor?)". ${ }^{61}$

A primeira seção de 0 conflito das faculdades ironiza sarcasticamente a superposição das faculdades superiores (teológica, jurídica e médica) à faculdade inferior (filosófica), como se tal constelação acadêmica cristalizasse o confronto entre heteronomia e autonomia, uma vez que nas superiores o governo ordena por meio de um contrato público (öffentlichen Vertrag) a quem ensina, enquanto a inferior só tem compromisso com a verdade, atenta que está à legislação da razão. 0 filósofo só 0 entende por que as coisas estão dispostas dessa maneira, invocan do a natureza humana. "Q ue uma tal faculdade", apostrofa Kant, "não obstante tal grande vantagem (da liberdade), é denominada inferior, reside na natureza do homem." Q uem pode mandar, porquanto seja um humilde servo de outrem, observa Kant, "imagina-se superior a um outro que, embora livre, não precisa dar ordens a ninguém". ${ }^{62} 0$ erudito em direito (Rechtsgelehrter) faz, de acordo com Kant, necessariamente mau uso da razão, ao buscar o critério geral (das allgemeineK riterium) que permite conhecer tanto o justo quanto o injusto em prescrições positivas, circunscritas ao tempo e espaço. Assim procedendo, dá a falsa impressão de que sua ciência tem o amparo de princípios simplesmente empíricos e dispõe, além disso, de uma regra positivada com vinculação coativa.

Tal suposta ciência do saber jurídico é comparável a uma cabeça de madeira (como a cabeça de madeira na fábula de Fedro), que "pode ser bonita", registra Kant, "mas que, lamentavelmente, não tem cérebro". ${ }^{63}$ Para o filósofo crítico, o jurista só é esclarecido quando faz uso público de seu entendimento, na contramão de toda e qualquer doutrinação, voltado à liberdade pública e não à mera tutela do povo. 


\section{Condusão}

Tomada ao pé da letra, a catilinária filosófica prescreve que o conhecimento do direito seja confiado exclusivamente ao filósofo. Contextualizado devidamente, 0 conflito das faculdades revela-se circunstanciado por acontecimentos desagradáveis na vida do filósofo, diante dos quais ele julgou-se legitimado para a autodefesa. ${ }^{64}$ Ao reagir contra 0 cerceamento da liberdade de expressão, Kant não altera sua posição doutrinária de direito e tampouco muda a concepção de um escalonamento diferenciado de competências jurídicas, definidas na D outrina do D ireito, de acordo com critérios formulados na introdução à $M$ etafísica dos costumes. ${ }^{65}$

$\mathrm{N}$ a ciência kantiana do direito, 0 direito positivo eo princípio jusnaturalista encontram-se sob os domínios da moral. As relações entre moral e direito não devem, para Kant, compor uma ordem comum de filiação, mas limitar-se a estabel ecer um índice remissivo recíproco entre 0 a priori sintético moral e o conceito analítico do direito. Por ser genuinamente prático, o primeiro exerce um papel crítico-normativo sobre o segundo, essencialmente metafísicoteórico. Em suma, a possibilidade de haver obrigações jurídicas se deve, em Kant, ao fato de os humanos terem à disposição uma efetiva obrigatoriedade moral.

ABSTRACT: O nly during the last decades, the $D$ octrine of Right returned to be of interest for those concerned themselves with philosophy. This text tries to show the Kantian science of right as part of Iluminism. The article privileges the rational character of the juridical conceptions of the $\mathrm{G}$ erman thinker.

Key words: Kant, faculty of coertion, rational right, philosophy of right.

\section{Notes}

1. "L'homme est né libre, et partout il est dans les fers [...]. Comment ce changement s'est-il fait? Je l'ignore. Q u'est-ce qui peut le rendre légitime? Je crois pouvoir résoudre cette question" (Rou sSEAu, Jean- 
J. 0 euvres complètes III (C ontract social I 1), Paris: Gallimard, 1964. p. 351. Versão portuguesa, p. 31).

2. KANT, Immanuel. Beantwortung der Frage: was ist A ufklärung/ Resposta à pergunta: que é "Esclarecimento"? (Versão portuguesa, p. 104).

3. Scheffel, D ieter. Kants kritische Verwerfung des Revolutionsrechts. In: Brandt, Reinhard. Rechtsphilosophie der Aufklärung. Berlin/ N ew York: de Gruyter, 1982. p. 178-217.

4. 0 texto de 1793 aborda a questão no contexto da história das religiões, mais especificamente em relação à controvérsia entre M endelssohn e Lessing. No primeiro suplemento da obra de 1795, Kant assevera que o progresso do gênero humano está assegurado pela natureza, através do mecanismo das inclinações humanas. 0 filósofo acrescenta, porém, que tal garantia é teoricamente incerta. No trabalho de 1798, Kant escreve que o fato de o gênero humano encontrar-se em constante progresso constitui uma asserção que resiste à mais exigente teoria.

5. Kant. Der Streit der Fakultäten. Hrsg. von Klaus Reich. Hamburg: Meiner, 1975. p. 84. (Versão portuguesa, p. 101-102).

6. Ibidem. Versão portuguesa, p. 102.

7. Rohden, Valério. Sociabilidade legal. U ma ligação entre direito e humanidade na 3. Crítica de Kant. Analytica. Rio de Janeiro, v. 1 n. 2, p. 97-106, 1994. ARENDT, Hannah. Lectures on Kant's political Philosophy. Chicago: The University of Chicago Press, 1982.

8. Em "Q u'est-ce que les L umières?" (1984), Foucault vê na segunda seção de $0 \mathrm{~s}$ conflitos das faculdades a continuidade de Was ist A ufklärung?, distinguindo ambos os textos das digressões kantianas sobre a questão da história. Foucault destaca sua originalidade, ao escrever: "Mais il existe dans la philosophie moderne et contemporaine un autre type de question, un autre mode d'interrogation critique: c'est celle que l'on voit naître justement dans la question de l'A ufklärung ou dans le texte sur la révolution; cette autre audition critique pose la question: 'Q u'est-ce que c'est que notre actualité? Q uel est le champ actuel des expériences possibles?'. II ne s'agit pas là d'une analytique de la verité, il s'agira de ce que l'on pourrait appeler une ontologie du présent, une ontologie de nous-mêmes 
[...]". In: Fou Cault, Michel. Dits et Écrits IV (1980-1988). Paris: Gallimard, 1994, p. 687. Cf. TerRA, Ricardo R. Foucault leitor de Kant: da antropologia à ontologia do presente, Analytica. Rio de Janeiro: v. 2, n. 1, p. 73-87, 1997.

9. Kant. Der Streit der Fakultäten. Hrsg. von Klaus Reich. Hamburg: Meiner, 1975. p. 84. (Versão portuguesa, p. 102-103).

10. Ibidem, p. 91. (Versão portuguesa, p. 109).

11. Ibidem, p. 87. (Versão portuguesa, p. 105).

12. Ibidem, p. 91. (Versão portuguesa, p. 109).

13. Ibidem, p. 92-93. (Versão portuguesa, p. 110).

14. Ibidem, p. 82. (Versão portuguesa, p. 100).

15. Ibidem, p. 83. (Versão portuguesa, p. 100-101).

16. Contrariamente a Kant, constituições modernas positivam um direito ativo à resistência (Art. 20, IV, da Lei Fundamental alemã). Sobre 0 direito à resistência na tradição cf. Su cu PIRA, N ewton. N ota sobre o direito de resistência ao governo tirânico ou a teoria do impeachment segundo Santo Tomás de Aquino. Revista Brasileira de Filosofia, São Paulo, v. XLIII, n. 181, 1996, p. 71-80. Kant advoga um direito restrito de desobediência civil, quando a obediência a uma ordem fere direta e imediatamente a lei moral. KANT. D ie Religion innerhalb der $\mathrm{G}$ renzen der blossen Vernunft. H rsg. von Karl Vorländer. 7. Aufl. Hamburg: Meiner, 1966. p. 106-107. (Versão portuguesa, p. 105).

17. HegeL, Georg, W.-F. G rundlinien der Philosophie des Rechts (parágrafo 145). H rsg. Von Johannes H offmeister. 4. Aufl. H amburg: M einer, 1955. p. 143. (Versão portuguesa, p. 98).

18. Ibidem (parágrafo 257), p. 207-208. (Versão portuguesa, p. 25).

19. Ibidem (parágrafo 260), p. 215. (Versão portuguesa, p. 36).

20. Kant. M etaphysische Anfangsgründe der Rechtslehre. Hrsg. von Bernd Ludwig. H amburg: Meiner, 1986. p. 140.

21. Cf. HerB, Karlfriedrich; Lu dW IG, Bernd. Kants kritisches Staatsrecht. Jahrbuch für Rechts und Ethik, Bd. 2, 1994. p. 431-478.

22. KAnT. M etaphysische A nfangsgründe der Tugendlehre (I ntrodução, B, VII). M etaphysik der Sitten. Hrsg. von Karl Vorländer. 4. Aufl. H amburg: 
M einer, 1966. p. 231: "As obrigações imperfeitas são, portanto, apenas obrigações da virtude".

23. Kersting, Wolfgang. Das starke Gesetz der Schuldigkeit und das schwächere der $\mathrm{G}$ ütigkeit. Recht, $\mathrm{G}$ erechtigkeit und demokratische Tugend. Abhandlungen zur praktischen Philosophie der Gegenwart. Frankfurt a/ Main: Suhrkamp, 1997. p. 74-124.

24. Hegel. Grundlinien der Philosophie des Rechts (parágrafo 258). H rsg. Von Johannes H offmeister. 4. Aufl. H amburg: M einer, 1955, p. 210. (Versão portuguesa, p. 28). As razões últimas dessa controvérsia são de ordem metafísica. A noção de casualidade (Zufälligkeit) ocupa nos dois autores uma lugar epistêmico diverso. Em Kant, a idéia de que algo seja casual assinala o respectivo marco inicial do filosofar, assim na questão da existência do primeiro homem, de seus primevos exercícios de liberdade, na recepção da R evolução Francesa ou na origem histórica do Estado. Para H egel, o casual é, enquanto necessidade do filosofar, igualmente in explicável, mas surge quando "o poder da unificação desaparece da vida dos homens" (C f. D ifferenz des Fichteschen und Schellingschen Systems der Philosophie - das Bedürfnis der Philosophie). Isso faz que o especulativo em Hegel mantenha por uma dialética reconstrutiva do que já não é mais, enquanto para Kant o que antecede ao filosofar é racionalmente incomensurável. Assim, anterior ao Estado há o provisório do incerto, por cima da lei moral o céu estrelado e ao lado do eu teórico o breu do vazio conceitual.

25. Frase conclusiva do anexo à Doutrina do direito. In: KANT. M etaphysische A nfangsgründe derR echtslehre (372, 20-25). H rsg. von Bernd Ludwig. H amburg: M einer, 1986. p. 200.

26. Ibidem (parágrafo 8, 256, 31-35), p. 63.

27. Ibidem (237, 39), p. 47.

28. I bidem (parágrafo 41, 1), p. 124.

29. Rou sseau . 0 euvres complètes III (C ontract social II 7). Paris: G allimard, 1964. p. 353. (Versão portuguesa, p. 99).

30. Hegel. Grundlinien der Philosophie des Rechts (parágrafo 297). H rsg. Von Johannes H offmeister. 4. Aufl. H amburg: Meiner, 1955. p. 258. (Versão portuguesa, p. 101): “O s membros do governo e os 
funcionários do Estado (Staatsbeamten) constituem a parte principal do estamento-médio, no qual se encontram a inteligência cultivada e a consciência jurídica da massa de um povo".

31. Kant. Beantwortung der Frage: was ist Aufkärung/ Resposta à pergunta: o que é "Esclarecimento"? Tradução do alemão por Floriano de S. Fernandes. (Versão portuguesa, p. 106).

32. I dem. Was heisst: sich im D enken orientieren/Q ue significa orientarse no pensamento? Tradução do alemão por Floriano de S. Fernandes. (Versão portuguesa, p. 92-94).

33. 0 interesse especulativo da razão abarca a expansão máxima do conhecimento empírico, orientado pela pergunta "O que posso conhecer?".

34. Kant. K ritik der praktischen Vernunft. 9. A ufl. H amburg: M einer, 1969. p. 3 e 17. [Tradução do alemão por Artur M orão. Lisboa: Edições 70. 1989. p. 11 e 24, respectivamente].

35. Idem. Was heisst: sich im Denken orientieren/Q ue significa: orientar-se no pensamento? Tradução do alemão por Floriano de S. Fernandes. (Versão portuguesa, p. 94).

36. Ibidem, p. 92-94.

37. Kant. Kritik der praktischen Vernunft. Hrsg. von Karl Vorländer. 9. Aufl. H amburg: Meiner, 1969. p. 100. (Versão portuguesa, p. 101102).

38. Ibidem, p. 38. (Versão portuguesa, p. 44).

39. Kant. M etaphysische A nfangsgründe der Rechtslehre (226, 12-13). H rsg. von Bernd Ludwig. Hamburg: Meiner, 1986. p. 23.

40. Ibidem (217, 7-10), p. 13.

41. I bidem (parágrafo $B, 230,28-30)$, p. 38.

42. Ibidem $(219,58-65)$ p. 29: “M as precisamente por isso, porque a legislação ética engloba em sua lei os móveis internos da ação (a idéia do dever), cuja determinação não tem de incorrer na legislação externa, ela não pode ser uma externa (nem mesmo a de uma vontade divina), muito embora ela assuma os deveres ancorados sobre uma outra legislação, a saber, externa, como deveres em sua legislação para motivos". 
43. O utra opinião: Boввı, N orberto. Autonomia e heteronomia. In: Direito e Estado no pensamento de Emanuel K ant. 2.ed. Tradução do italiano por Alfredo Fait. Brasília: Editora U niversidade de Brasília, 1992. p. 62-66.

44. TERRA, Ricardo. A política tensa. Idéia e realidade na filosofia da história de Kant. São Paulo: Iluminuras, 1995. p. 63. Cf. também KERSTING. W ohlgeordnete Freiheit: Immanuel Kants Rechts- und Staatsphilosophie. Frankfurt a/ Main: Suhrkamp, 1993.

45. KöNIG, Peter. A utonomie und A utokratie. Ü ber Kants M etaphysik der Sitten. Berlin/ N ew York: de Gruyter, 1994.

46. Kant. K ritik der U rteilskraft. H rsg. von Karl Vorländer. 6. Aufl. H amburg: M einer, 1968. p. 145. (Versão portuguesa, p. 140).

47. Ibidem, p. 146, nota de rodapé. (Versão portuguesa, p. 141).

48. C f. as digressões terminológicas so bre das Böse e das $G$ ute, bem como a avaliação do celerado por nascimento (Bösewichter) na C rítica da Razão Prática (104-108 e 178-179, respectivamente).

49. Kant. M etaphysische A nfangsgründe der Rechtslehre (parágrafo $52 \mathrm{~A}$, 322, 3-6). Hrsg. von Bernd Ludwig. Hamburg: Meiner, 1986. p. 144: "Soviel wir einsehen, ist ein dergleichen Verbrechen einer förmlichen (ganz nutzlosen) Bosheit zu begehen, Menschen unmöglich, und doch (obzwar blosse Idee des Äusserst-Bösen) in einem System der Moral nicht zu übergehen".

50. A expressão é utilizada por Kant ao final do texto de 1786 (nota de rodapé), quando define o que é "pensar por si mesmo", contrastan do Selbstdenken com superstição e devaneio. KANT. Was heisst: sich im Denken orientieren? Tradução do alemão por Floriano de S. Fernandes. (Versão portuguesa, p. 98-99).

51. Kant. Der Streit der Fakultäten. Hrsg. von Klaus Reich. Hamburg: Meiner, 1975. p. 89. (Versão portuguesa, p. 106-107).

52. I dem. M etaphysische A nfangsgründe der Rechtslehre (237, 38-39). H rsg. von Bernd Ludwig. Hamburg: Meiner, 1986. p. 47.

53. Ibidem (224, 10-16). p. 26. Embora admita que possa haver uma legislação composta exclusivamente de leis positivas, o efeito vinculador de tal complexo legal exigiria, para Kant, a pré-vigência de uma lei natural, "que fundamentasse a autoridade do legislador 
(isto é, o poder de vincular outros por mero arbítrio seu", uma vez que nenhuma lei estatutária pode anular a igualdade inata do ser humano.

54. Ibidem (parágrafo C, 231, 11-14), p. 39.

55. Ibidem (parágrafo C, 231, 9-10), p. 39.

56. Ibidem (parágrafo C, 231, 20-23), p. 39.

57. Höffe, Otfried. O imperativo categórico do direito: uma interpretação da "Introdução à Doutrina do Direito". Studia K antiana. Rio de Janeiro, v. 1, n. 1, 1998. p. 223.

58. LudwIG, Bernd. K ants Rechtslehre. Hamburg: Meiner, 1988, p. 95.

59. Kant. Der Streit der Fakultäten. H rsg. von Klaus Reich. Hamburg: M einer, 1975. p. 15: "D aher schöpft der biblische Theolog (als zur obern Fakultät gehörig) seine Lehren nicht aus der Vernunft, sondern aus der Bibel, der Rechtslehrer nicht aus dem $\mathrm{N}$ aturrecht, sondern aus dem Landrecht, der Arzneigelehrte seine ins Publikum gehende $\mathrm{H}$ eilmethode nicht aus der Physikdes menschlichen Körpers, sondern aus der M edizinalordnung". (Versão portuguesa, p. 25).

60. Ibidem, p. 15. (Versão portuguesa, p. 25-26).

61. Ibidem, p. 28-29. (Versão portuguesa, p. 40).

62. Ibidem, p. 12. (Versão portuguesa, p. 22).

63. Kant. M etaphysische A nfangsgründe der Rechtslehre (224, 10-17 e 229, 5-17). H rsg. von Bernd Ludwig. Hamburg: Meiner, 1986. p. 26 e 37.

64. Em outubro de 1794, Kant fora instado a submeter-se à censura das autoridades governamentais de Berlim. 0 filósofo acabou concordando, em correspondência ao rei da Prússia, em silenciar em público sobre matéria religiosa no futuro. Em 1797 a legislação antiiluminista foi revogada, e Kant não mais viu razões para manter a promessa. 0 prefácio de 0 conflito das faculdades contém um amargurado necrológio sobre o falecido rei prussiano, Frederico Guilherme II. N a primeira parte do livro, Kant volta à carga com as teses expostas no livro A religião e rei vindica para a faculdade inferior - a filosófica - o direito de examinar a verdade dos estatutos das três faculdades superiores (Teologia, Direito e M edicina). 
65. Kant. M etaphysische Anfangsgründe der Rechtslehre (230, 5-8). H rsg. von Bernd Ludwig. Hamburg: Meiner, 1986. p. 38.

\section{Referênaias}

Adeodato, João M . 0 problema da legitimidade. No rastro do pensamento de Hannah A rendt. Rio de Janeiro: Forense, 1989.

Arendt, $\mathrm{H}$ annah. Lectures on Kant's political philosophy. Chicago: The University of Chicago Press, 1982.

Bоввıо, N orberto. Autonomia e heteronomia. Direito e E stado no pensamento de Emanuel K ant. 2.ed. Tradução do italiano por A. Fait. Brasília: Editora U niversidade de Brasília, 1992.

Brandt, Reinhard. Rechtsphilosophie der Aufklärung. Berlin, New York: de Gruyter, 1982.

Fou cault, M ichel. Dits et É crits IV (1980-1988). Paris: G allimard, 1994. Fulda, H.-F. Deduktion der Einteilung eines Systems - erörtert am Beispiel Metaphysische Anfangsgründe der Rechtslehre. In: FuLDA; Stolzenberg (H rsg.). A rchitektonik und System in der Philosophie Kants. H amburg: M einer, 2001.

GúnTHer, Klaus. Kann ein Volk von Teufeln Recht und Staat moralisch legitimieren? $\mathrm{O}$ tfried $\mathrm{H}$ öffes Beitrag zum N eo-N aturrecht. In: KERSTING, Wolfgang. G erechtigkeit als Tausch. Auseinandersetzungen mit der politischen Philosophie 0 tfried Höffes. Frankfurt a/ Main: Surhkamp, 1997.

HECK, José $N$. Autonomia, sentimento de respeito e Direito. Veritas, $v$. 46, n. 4. Porto Alegre, 2001.

Hegel, Georg, W.-F. G rundlinien der Philosophie des Rechts. H rsg. von Johannes H offmeister. 4. Aufl. H amburg: M einer, 1955. [Tradução do alemão por M. Müller. Campinas: Editora da Unicamp, 1998.]

HERB, Karlfriedrich; LudWIG, Bernd. Kants kritisches Staatsrecht. In: Jahrbuch für Rechts und Ethik. Munique, Bd. 2, 1994.

H öFfE, O tfried. O imperativo categórico do direito: uma interpretação da "Introdução à D outrina do Direito". Studia K antiana, Rio de Janeiro, 
v. 1, n. 1, 1998. [Versão alemã: Der kategorische Rechtsimperativ "Einleitung in die Rechtslehre". Immanuel Kant. M etaphysische A nfangsgründe der Rechtslehre. Berlin: Akademie Verlag, 1999 (Klassiker Auslegen)].

. Ist Kants Rechtsphilosophie noch aktuell? Immanuel Kant. M etaphysische A nfangsgründe der Rechtslehre. Berlin: A kademie Verlag, 1999 (Klassiker Auslegen)].

KANT, Immanuel. Beantwortung der Frage: was ist A ufklärung/ Resposta à pergunta: que é "Esclarecimento"? Tradução do alemão por F. Fernandes. Textos seletos. 2.ed. Petrópolis: Vozes, 1985. [Edição bilíngüe].

. Was heisst: sich im Denken orientieren/Q ue significa: orientarse no pensamento? Tradução do alemão por F. Fernandes. Textos seletos. 2.ed. Petrópolis: Vozes, 1985. [Edição bilíngüe].

. K ritik der praktischen Vernunft. 9. Aufl. H amburg: M einer, 1969. [Tradução do alemão por A. M orão. Lisboa: Edições 70, 1989].

. K ritik der U rteilskraft. H rsg. von Karl Vorländer. 6. Aufl. Hamburg: Meiner, 1968. [Tradução do alemão por V. Rohden e A. Marques. Rio de Janeiro: Forense U niversitária, 1993].

Die Religion innerhalb der $\mathrm{G}$ renzen der blossen Vernunft. H rsg. von Karl Vorländer. 7. Aufl. H amburg: M einer, 1966. [Tradução do alemão por A. Morão. Lisboa: Edições 70, 1992].

. M etaphysische A nfangsgründe der Rechtslehre. H rsg. von Bernd Ludwig. Hamburg: Meiner, 1986.

. M etaphysik der Sitten. H rsg. von Karl Vorländer. 4. Aufl. H amburg: M einer, 1966.

. Der Streit der Fakultäten. H rsg. von Klaus Reich. H amburg: M einer, 1975. [Tradução do alemão por A. Morão. Lisboa: Edições 70, 1993].

KeRSTING, W olfgang. W ohlgeordnete Freiheit: I mmanuel Kants Rechts-und Staatsphilosophie. Frankfurt a/ M ain: Suhrkamp, 1993.

. Das starke Gesetz der Schuldigkeit und das schwächere der G ütigkeit. In: Recht, G erechtigkeit und demokratische Tugend. A bhandlungen 
zur praktischen Philosophie der Gegenwart. Frankfurt a/ M ain: Suhrkamp, 1997.

. Politik und Recht. Abhandlungen zur politischen Philosophie der Gegenwart und zur neuzeitlichen Rechtsphilosophie. Weilerswist: Velbrück W issenschaft, 2000.

. K ritik der G leichheit. Ü ber die Grenzen der Gerechtigkeit und der M oral. Weilerswist: Velbrück W issenschaft, 2002.

KöNIG, Peter. Autonomie und Autokratie. Ü ber Kants Metaphysik der Sitten. Berlin/ N ew York: de Gruyter, 1994.

Lo PARIC, Zeljko. 0 fato da razão: uma interpretação semântica. A nalytica, Rio de Janeiro, v. 4, n. 1, 1999.

LUDWIG, Bernd. K ants Rechtslehre. H amburg: M einer, 1988.

Lu fT, Eduardo. Sementes da dúvida. Investigação crítica dos fundamentos da filosofia hegeliana. São Paulo: Mandarim, 2001.

Platão. A república. Livro VII. Tradução de E. Marcelina. São Paulo: Ática: Editora da UnB, 1989.

RoHden, Valério. Sociabilidade legal. U ma ligação entre direito e humanidade na 3. Crítica de Kant. A nalytica. Rio de Janeiro, v. 1, n. 2, 1994.

Ro u sSEAu, J ean-J. 0 euvres complètes III. Paris: G allimard, 1964. [Tradução do francês por L. Machado. São Paulo: Nova Cultural, 1987. (O s Pensadores)].

Scheffel, Dieter. Kants kritische Verwerfung des Revolutionsrechts. In: Brandt, Reinhard. Rechtsphilosophie der Aufklärung. Berlin/ New York: de Gruyter, 1982.

Sucupira, N ewton. N ota sobre o direito de resistência ao governo tirânico ou a teoria do impeachment segundo Santo Tomás de Aquino. Revista Brasileira de Filosofia. São Paulo, v. XLIII, n. 181, 1996.

TERRA, Ricardo. A política tensa: idéia e realidade na filosofia da história de Kant. São Paulo: Iluminuras, 1995.

Foucault leitor de Kant: da antropologia à ontologia do presente. Analytica, Rio de Janeiro, v. 2, n. 1, p. 73-87, 1997. 
. N otas sobre o conceito de passagem (Ü bergang) no pensamento kantiano. In: M ARQu Es, Edgar et al. (O rg.). Verdade, conhecimento e ação. Ensaios em homenagem a Guido de Almeida e Raul Landim Filho. São Paulo: Loyola, 1999. p. 401-408.

W ood, Allen W. Kant's doctrine of right: Introduction. In: Höffe, 0. (H rsg.). I mmanuel K ant: M etaphysische A nfangsgründe der Rechtslehre. Berlin: Akademie Verlag, 1999. (Klassiker Auslegen). 